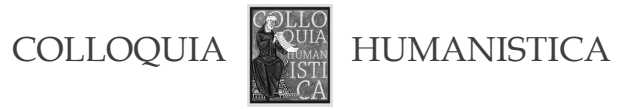

\title{
Jolanta Sujecka
}

Institute of Slavic Studies

Polish Academy of Sciences

Warsaw

\section{Profile of Grigor Prličev (Grigorios Stawridis)}

he poet Grigor Prličev was born in the Macedonian city of Ohrid,
most probably in 1830, or according to other sources, in 1831 . He composed poetry in Greek and translated ancient and modern Greek literature. He was taught by Dimitar Miladinov (1810-1862) known in

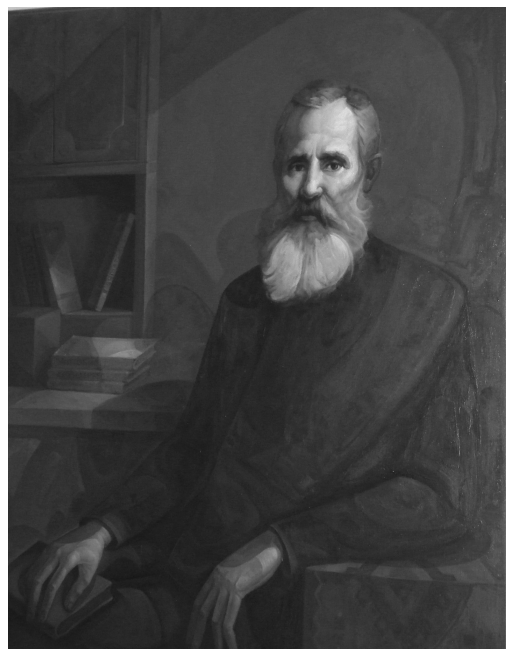

Grigor Prličev

painted by Kole Manev. From the collection of the Macedonian Academy of Sciences and Arts this period for his educational activities among Slavs from the territory of Turkish Macedonia; Miladinov was initially a Hellenophile, later a misohellene and a Slavophile; with his brother Konstantin (1830-1862) he collected and published in Zagreb in 1861 folk songs from "Bulgaria and Western Bulgaria, i.e. Macedonia," as Konstantin wrote in his announcement of the famous publication ${ }^{1}$ in the periodical “Дунавски лебед” (“The Danube Swan”), published in Belgrade in 1860-61 by Georgi Sava Rakowsky (1821-1867), a Bulgarian poet, journalist and activist for the cause of religious and educational autonomy among Slavs living in Turkish territories.

\footnotetext{
1 The title of the collection of folk songs Б'лгарски народни п'сни confirms the lack of ideological character in mid 19th century of the lexeme Macedonia / Macedonian treated exclusively as the name of the territory, i. e. in the same way the lexeme functioned in the memory of the inhabitants of the Ottoman empire. This is why the Macedonian intelligentsia who collaborated with Bulgarians could use the term Bulgarian to denote their own identity.
} 
In 1849-50 and in 1859-60 Prličev studies medicine in Athens, at the same time preparing as an entry to a poetry competition 'O 'A $\mu \alpha \tau \tau \omega \lambda$ 's (Armatol), ${ }^{2}$ a poem in katareousa, a sophisticated variety of Modern Greek, different from the ordinary spoken language. In 1860 he is awarded the main prize for the poem at the Athenian contest and the prestigious title of the "second Homer," along with a bursary making it possible for him to study at Oxford. In accordance with a previous decision, he allots part of the prize for a stipend for an impecunious student; he quickly spends the remaining money and declines the bursary for the study abroad opting for the return to his native Ohrid. His decision is prompted by the arrest of first Dimitar, and later also Konstantin Miladinov in Istambul and their sudden death in circumstances not entirely explained.

In 1862 he enters another of his poems $\Sigma \kappa \varepsilon v \delta \varepsilon \dot{\rho} \mu \pi \varepsilon \eta \varsigma$ (Skenderbej) at the next poetry competition in Athens; it was noticed by the contest committee but not awarded a prize. In 1868 he begins his study of Bulgarian, or, as he calls it himself the Slavonic language, under the instruction of Iwan Najdenov, a Bulgarian teacher and journalist living in Istanbul. The study was intended to encourage him to translate into this newly acquired language Homer's Iliad. ${ }^{3}$ The translation met with little success, a fact noted by the contemporary Bulgarian critics, especially Nesho Bonchev, the first acclaimed Bulgarian translator of the Greek original of Homer's epic.

While painful the criticism did not surprise Prličev, because his knowledge of Bulgarian was still recent and superficial, as he records himself in his Aвmoбиограбиja (Autobiography, 1894) written at the end of his life in the Slavonic language, with numerous Turkish, Greek and dialectal expressions used in his native city of Ohrid, ${ }^{4}$ and published in Sofia in a Bulgarian periodical "Сборник на народни умотворения наука и книжнина," produced by the Bulgarian Ministry of Education of the time.

The fact that Prličev's Autobiography was published without any editorial vetting did not mean that the contemporary elites of the newly restored, young Bulgarian state in any way recognized the potentially distinctive Macedonian separatism..$^{5}$ On the contrary, the editors of the Bulgarian

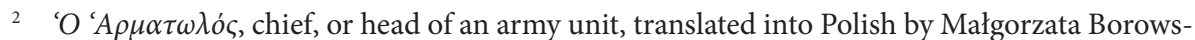
ka as Armatol; it was rendered many times into Macedonian, e.g. by Georgi Stalev via Bulgarian as Cepдарот (1971), by Mihail Petruševski from the Greek original as Мартолозот (1983).

3 The language of Homer's Iliad was, as Prličev calls it himself Common "Slawonic."

4 Автобиограббиja was written in $1884 / 85$; it covers the author's life from birth to the 1880 s.

5 In 1891-92 in Sofia, young people from Turkish Macedonia form a group around the periodical „Лоза," closed down after 6 issues because of the nascent, so-called Macedonian "separatism" reflected in the publication. The real cause of the liquidation of the periodical was the attempt to introduce orthographic rendering the distinctive Macedonian Slavonic phonetics. These were the four consonants: $\hat{K}^{\prime}(\mathrm{kj}), \dot{r}(\mathrm{gj})$, њ (nj), љ (lj). 
scholarly journal viewing the language of the Autobiography as characteristic for contemporary Slavonic inhabitants of Ohrid who passed for Bulgarians, considered important „to preserve it in its entirety without losing anything from its original character." Indeed, the editorial vetting was limited to amending the punctuation applied by Prličev according to the Greek usage.

The firm integration in the Greek culture and language gave to Prličev the possibility of communicating with the contemporary cultural world but it also made him sensitive to the nascent national identity distinctions among the formerly unified although ethnically not homogenous Turkish Balkans. The Greek national renaissance on one hand, and the Bulgarian religious and identity movement on the other, were both sources of inspiration for the poet from Ohrid. The concept of a common Slavonic language was born; it influenced creatively and energetically the nation-forming tendencies of the mid 19th century. Prličev's idée fixe, was in fact late by a century: a hundred years earlier it inspired many people in the Balkans and in the surrounding regions. While the idea proposed by the author of Armatol did not attract supporters among the Slavonic elites in the Balkans, it surprisingly suited his poetic philosophy, in particular his characters, truly Homeric in outlook, uninvolved in any national particularities, even if emotionally connected to their small, regional and local homeland.

Armatol's author functions in three discourses: in Bulgarian as Григор Пърличев, in Macedonian as Григор Прличев (Grigor Prličev), and finally in Greek - in his own time and now in the cyberspace of today - as Grigorios Stawridis.

For this reason, the form of his first and family names suggested below by the translator, Hellenist and Neo-Hellenist, Małgorzata Borowska, is a Polonized version of the Greek notation, occurring in the first Greek edition of the poem 'O 'A $\rho \mu \alpha \tau \omega \lambda$ 's (Armatol) signed with that version of the name. 